\title{
Analisis Perbandingan Usability Website E-Commerce Konveksi Menggunakan Metode Eye-Tracking
}

\section{Tugas Akhir}

Diajukan Untuk Memenuhi

Persyaratan Guna Meraih Gelar Sarjana

Informatika Universitas Muhammadiyah Malang

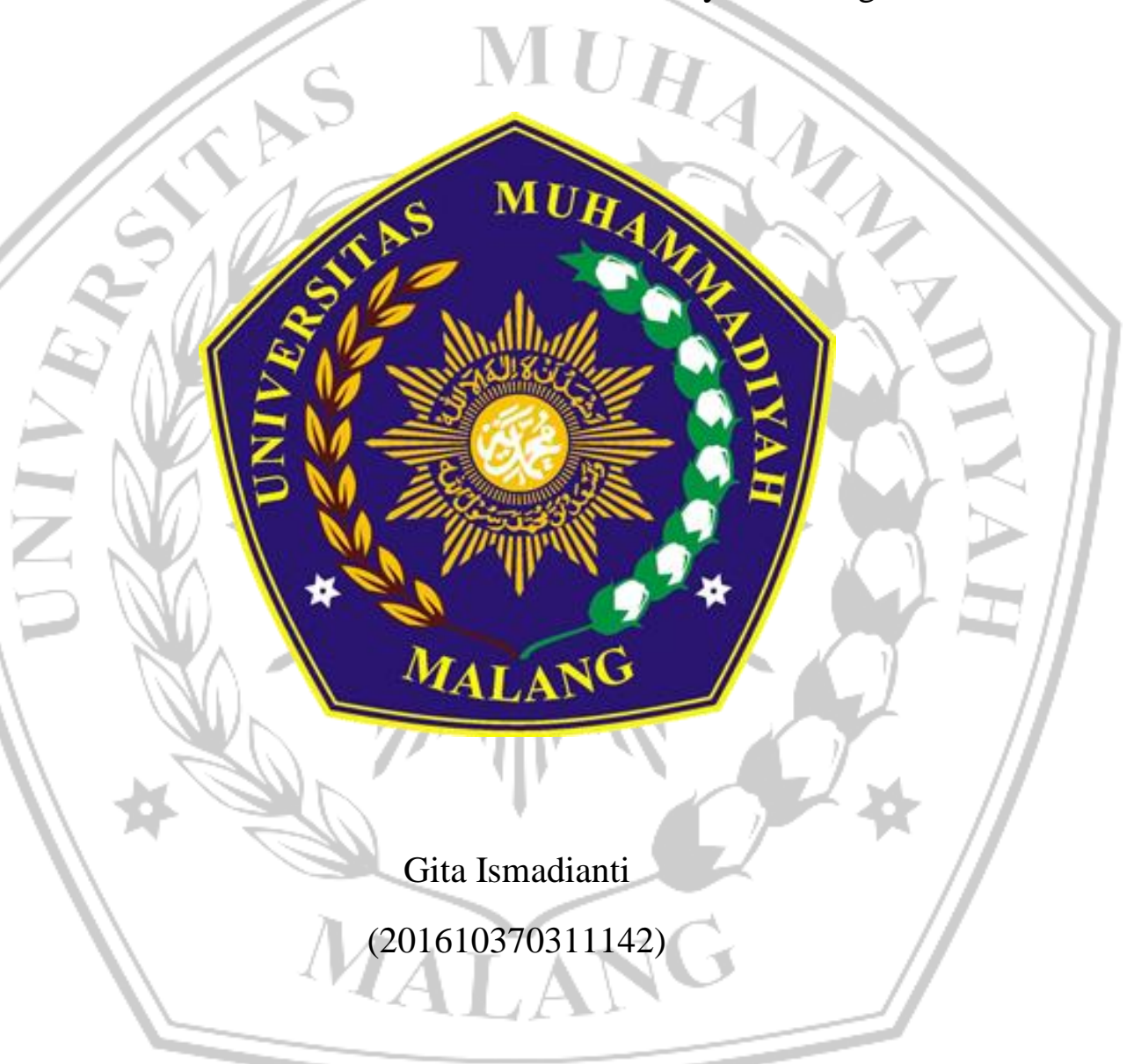

Rekayasa Perangkat Lunak

PROGRAM STUDI INFORMATIKA

FAKULTAS TEKNIK

UNIVERSITAS MUHAMMADIYAH MALANG 


\section{LEMBAR PERSETUJUAN}

Analisis Perbandingan Usability Website E-Commerce Konveksi Menggunakan Metode Eye-Tracking

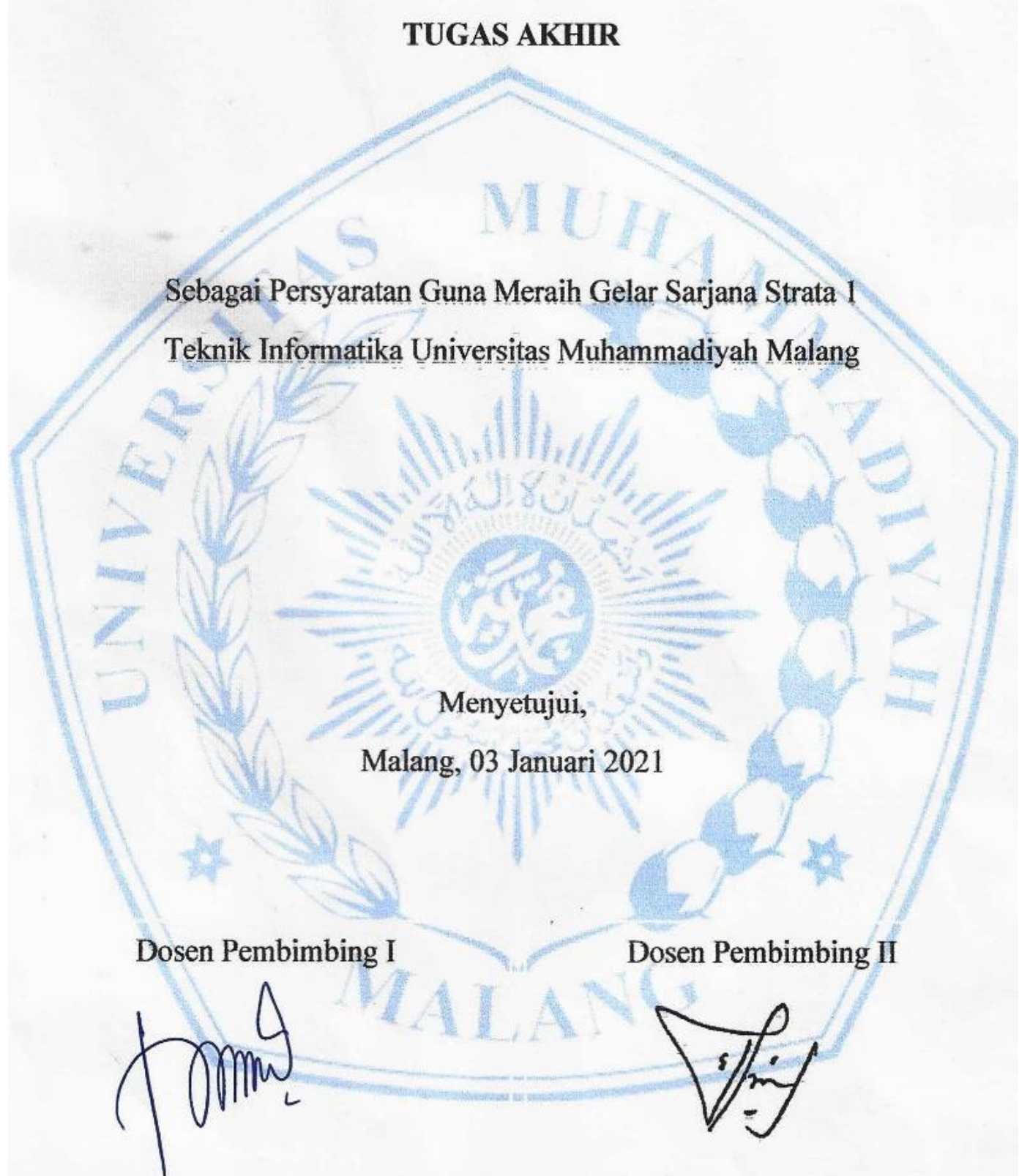

Gita Indah Marthasari, S.T, M.Kom Evi Dwi Wahvuni, S.Kom, M.Kom NIP.108.0611.0442 NIP.108.1703.0595 


\section{LEMBAR PENGESAHAN}

\section{Analisis Perbandingan Usability Website E-Commerce Konveksi \\ Menggunakan Metode Eye-Tracking}

\section{Tugas Akhir}

Sebagai Persyaratan Guna Meraih Gelar Sarjana Strata 1

Teknik Informatika Universitas Muhammadiyah Malang

Disusun Oleh:

\section{Gita Ismadianti}

201610370311142

Tugas Akhir ini telah diuji dan dinyatakan lulus melalui sidang majelis penguji pada tanggal 08 Januari 2021

\section{Menyetujui,}

Dosen Penguji I

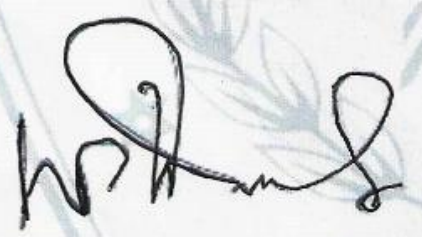

Wildan Suharso, S.Kom, M.Kom NIDN. 0730038405
Dosen Penguji II

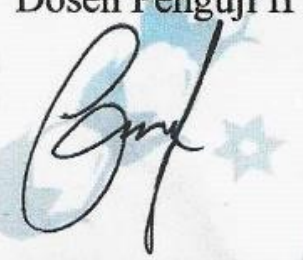

Christian SK Aditya,S.Kom,M.Kom NIDN 0727029101 Mengetahui,

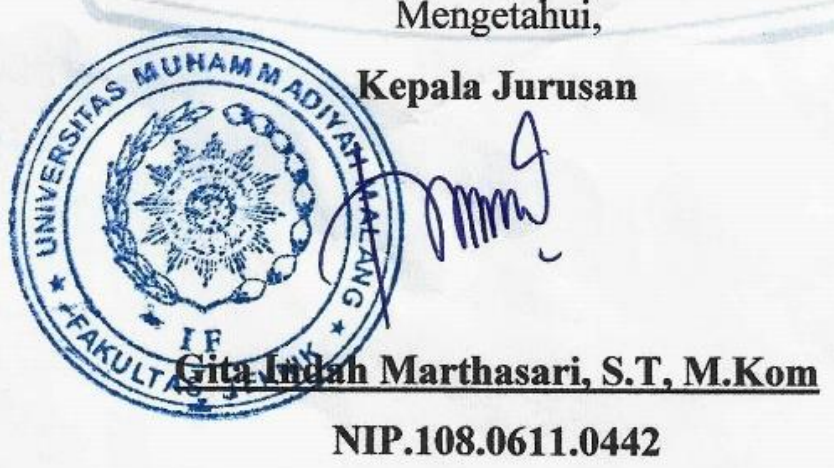




\section{LEMBAR PERNYATAAN}

Yang bertanda tangan di bawah ini:

Nama

: Gita Ismadianti

Tempat, Tanggal Lahir

: Jombang, 30 Maret 1998

NIM

: 201610370311142

Fakuitas / Jurusan

: Teknik / Informatika

Dengan ini saya menyatakan bahwa Tugas Akhir dengan judul "Analisis Perbandingan Usability Website E-Commerce Konveksi Menggunakan Metode Eye-Tracking" beserta seluruh isinya adalah karya saya sendiri dan bukan merupakan karya tulis orang lain, baik sebagian maupun keseluruhan, kecuali dalam bentuk kutipan yang telah disebutkan sumbernya.

Demikian surat pernyataan ini saya buat dengan sebenar-benarnya. Apabila kemudian ditemukan adanya pelanggaran terhadap etika keilmuan dalam karya saya ini atau ada klaim dari pihak lain terhadap keaslian karya saya ini maka saya siap menanggung segala bentuk resiko/sanksi yang berlaku.

Mengetahui,

Dosen Pembimbing

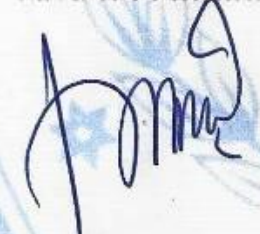

Gita Indah Marthasari, S.T, M.Kom
Malang, 03 Januari 2021

Yang Membuat Pernyataan

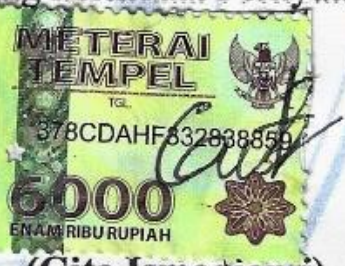

(Gita Ismadianti) 


\section{KATA PENGANTAR}

Alhamdulillahi rabbil 'alamin, dengan memanjatkan puji dan syukur kehadirat Allah SWT yang telah melimpahkan rahmat dan hidayah-Nya. tak lupa shalawat serta salam kepada junjungan Nabi Besar Muhammad SAW, sehingga skripsi berjudul "Analisis Perbandingan Usability Website E-Commerce Konveksi Menggunakan Metode Eye-Tracking” dapat terselesaikan.

Tugas akhir ini ditulis dalam rangka memenuhi syarat untuk memperoleh gelar sarjana komputer bagi mahasiswa program S1 pada studi Teknik Informatika Universitas Muhammadiyah Malang. Penulis menyadari bahwa tugas akhir ini masih banyak terdapat kekurangan, oleh sebab itu penulis mengharapkan kritik dan saran yang bersifat membangun dari semua pihak demi kesempurnaan tugas akhir ini.

Penyelesaian skripsi ini tidak lepas dari dukungan dan bantuan berbagai pihak, baik secara langsung maupun tidak langsung. Oleh karena itu, pada kesempatan ini penulis dengan segala kerendahan hati mengucapkan terima kasih dan penghargaan yang sebesar-besarnya kepada:

1. Allah SWT yang selalu memberikan kemudahan dan kesabaran dalam mengerjakan tugas akhir ini.

2. Orang tua saya, adik/saya tercinta saya, serta keluarga besar saya. Terima kasih atas segala dukungan, motivasi, dan nasehat yang terus menerus tiada henti.

3. Dosen pembimbing saya, Bu Gita Indah Marthasari, S.T, M.Kom dan Bu Evi Dwi S.Kom, M.Kom yang sudah bersedia dan meluangkan waktunya untuk membimbing dan memberi masukan terkait tugas akhir ini.

4. Terimakasih juga untuk ibu Gita Indah Marthasari, S.T, M.Kom ketua prodi jurusan Informatika dan bapak ibu Dosen Pengajar yang telah memberikan ilmunya selama saya kuliah, berserta Staff TU Jurusan Teknik Informatika. 
5. Terimaksih untuk sahabat seperjuangan saya Riana, Tilla, Lila, Salma, Dimas, Fakhri, Rezky, dan lainnya yang tak bisa saya sebutkan satu per satu. Terima kasih atas dukungan kalian.

Malang, 03 Januari 2021

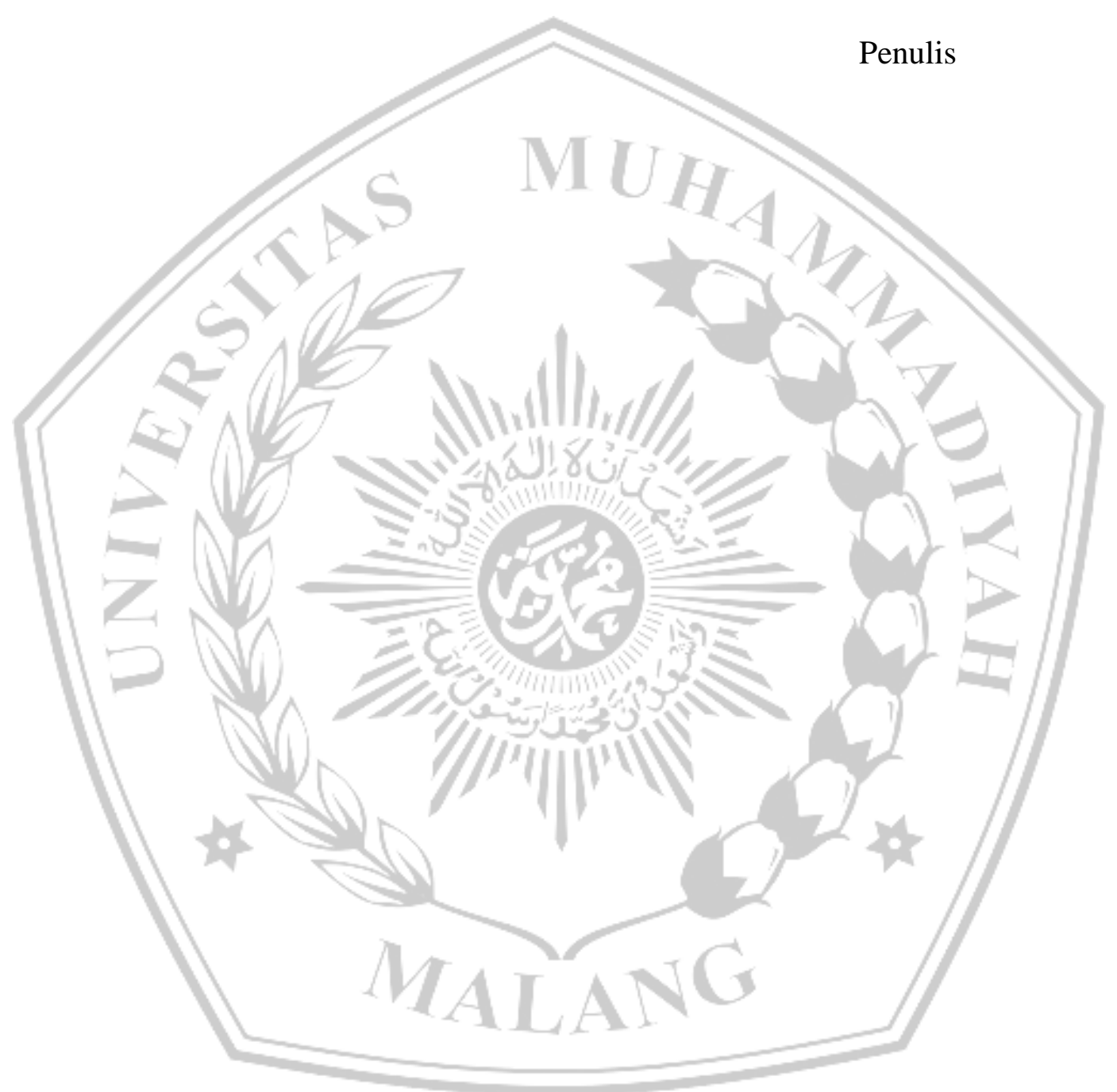




\section{DAFTAR ISI}

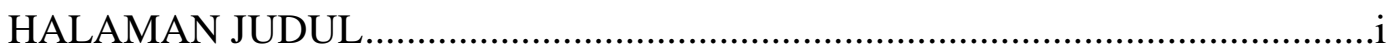

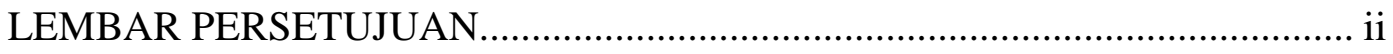

LEMBAR PENGESAHAN _..................................................................... ii

LEMBAR PERNYATAAN ...............................................................................

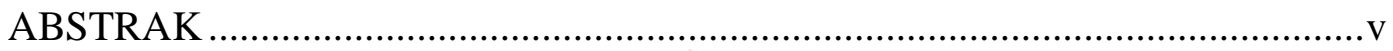

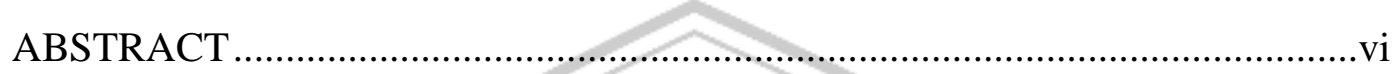

KATA PENGANTAR ..................................................................... vii

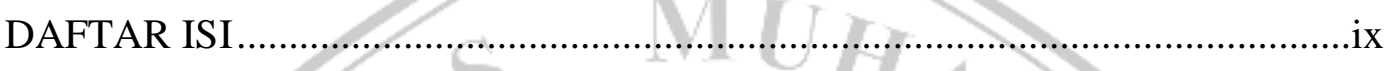

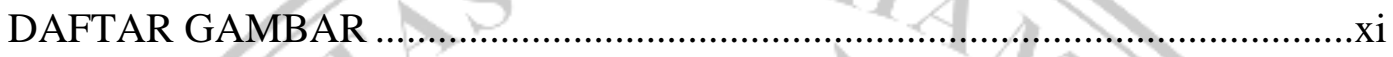

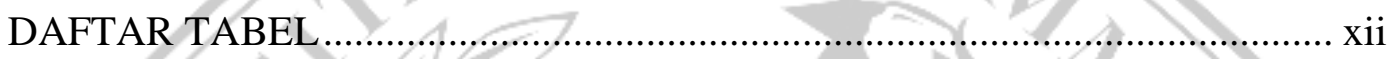

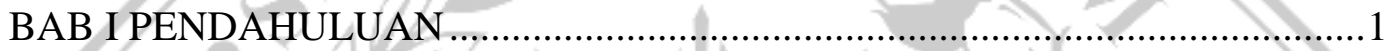

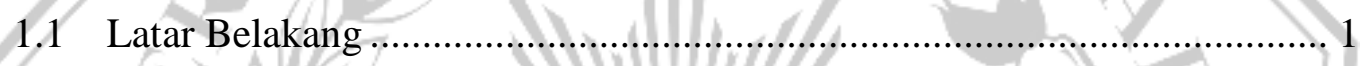

1.2 Rumusan Masalah ................................................................... 4

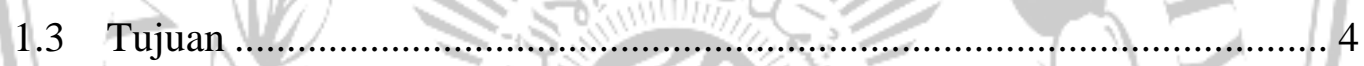

1.4 Batasan Masalah........................................................................ 4

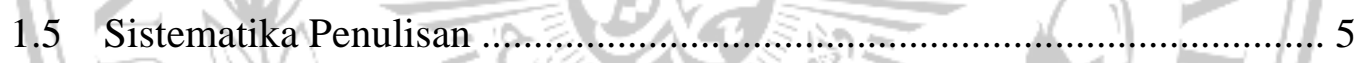

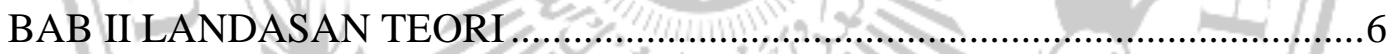

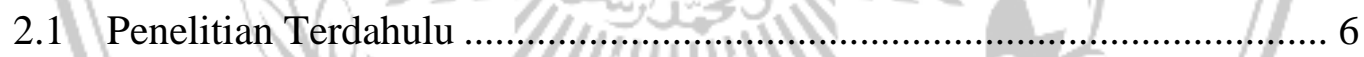

2.2 Website Azstore.id dan kaos3dmalang.com ....................................... 8

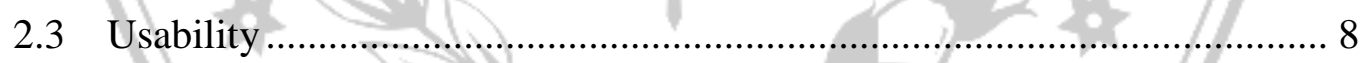

2.4 Usability Menggunakan USE Questionnaire ….................................... 9

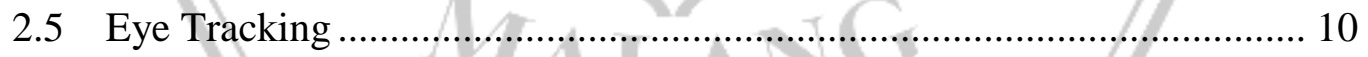

2.6 Skala Pengukuran Kuesioner ............................................................... 11

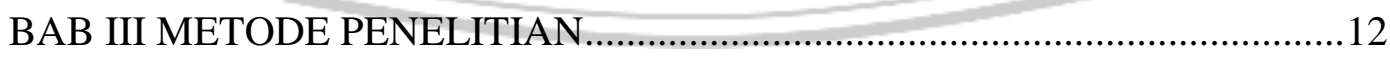

3.1 Metodologi Penelitian .................................................................... 12

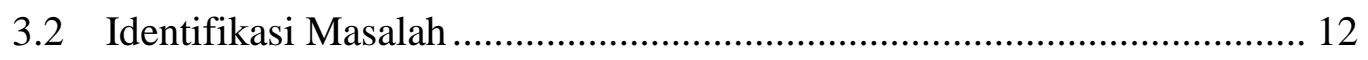

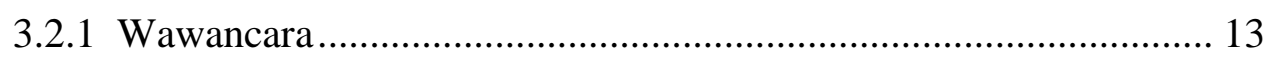

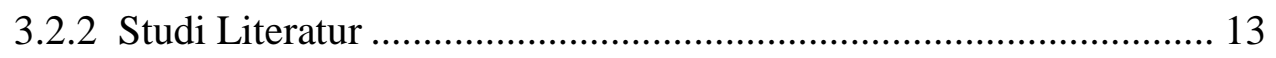

3.3 Perancangan dan Pembuatan Task Untuk Kuesioner............................... 13

3.4 Pengumpulan Data ............................................................................ 16 
3.4.1. Populasi dan Sample 16

3.4.2. USE Questionnaire. 17

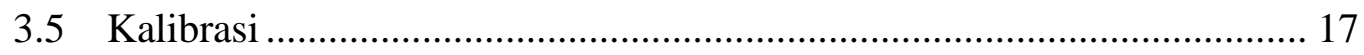

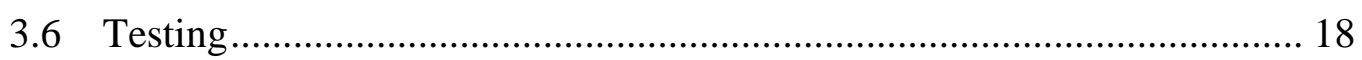

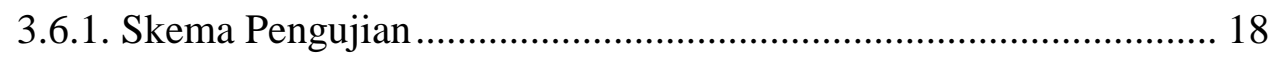

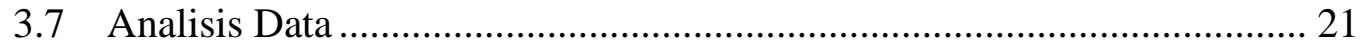

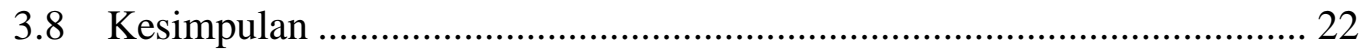

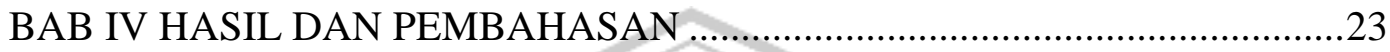

4.1 Hasil dan Pembahasan ................................................................... 23

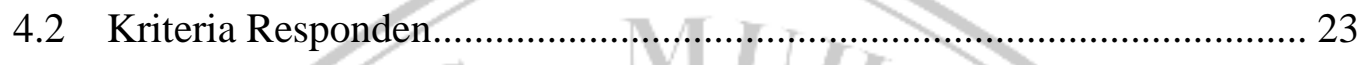

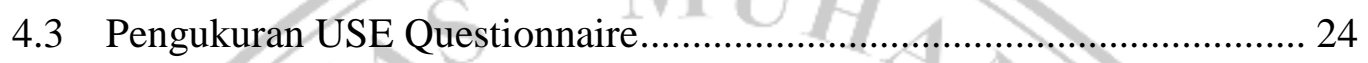

4.3.1. Pengukuran Usability Website Azstore.id ................................. 25

4.3.2. Pengukuran Usability Website kaos3dmalang.com..................... 25

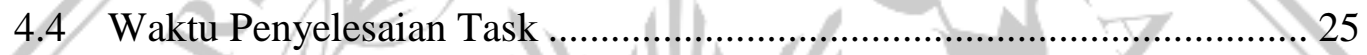

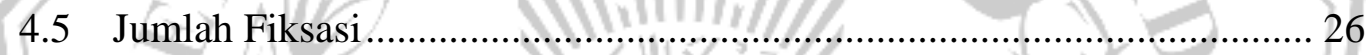

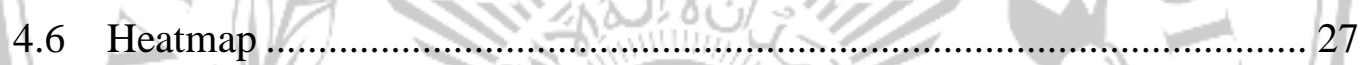

4.7 Korelasi USE Questionnaire dan Metode Eye-tracking........................ 30

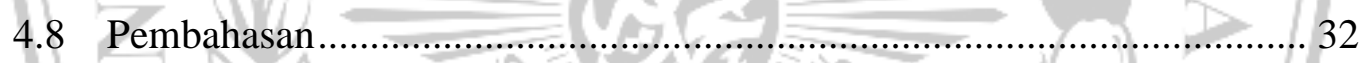

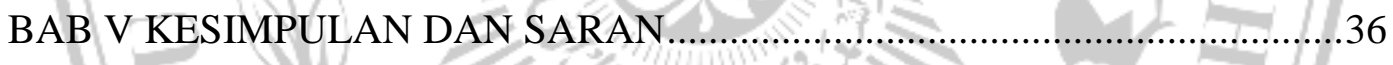

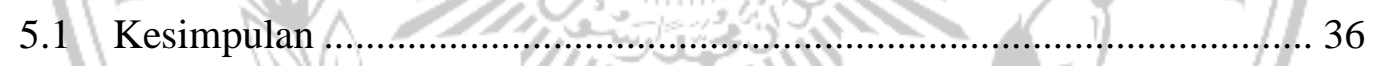

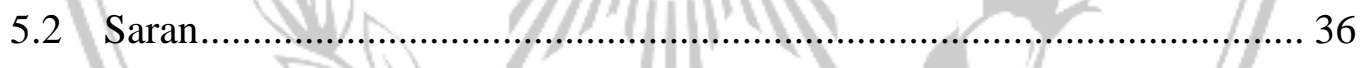

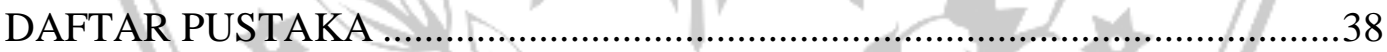




\section{DAFTAR GAMBAR}

Gambar 2.1. Kriteria Pengujian USE .......................................................... 10

Gambar 3.1. Metode Penelitian ......................................................................... 12

Gambar 3.2. Task 1 (Mencari video promosi kaos) ............................................ 19

Gambar 3.3. Task 2 (Mencari Tulisan Kaos Dewasa)........................................ 19

Gambar 3 4. Task 3 (Mencari Button Pesan Sekarang) ................................... 20

Gambar 3.5. Task 1 (Menemukan produk kaos 3d malang) ............................ 20

Gambar 3.6. Task 2 (menemukan sub menu tentang kami) ............................. 21

Gambar 3.7. Task 3 (button hubungi kami) .................................................. 21

Gambar 4.1. Frekuensi Pengunjungan Website E-commerce Grup responden A24

Gambar 4.2. Frekuensi Pengunjungan Website E-commerce Grup responden B24

Gambar 4.3. Diagram Rata-Rata Jumlah Fiksasi ........................................ 27

Gambar 4.4. Task 1 (Cobalah temukan Video promosi kaos) ......................... 28

Gambar 4.5. Task 2 (Carilah dan temukan tulisan ukuran kaos dewasa).......... 28

Gambar 4.6. Task 3 (Carilah Button Pesan Sekarang) ................................... 29

Gambar 4.7. Carilah dan temukan tulisan make your desaign here .................. 29

Gambar 4.8. Carilah dan temukan submenu tentang kami............................. 30

Gambar 4.9. Cobalah button hubungi kami (wa) ........................................ 30 


\section{DAFTAR TABEL}

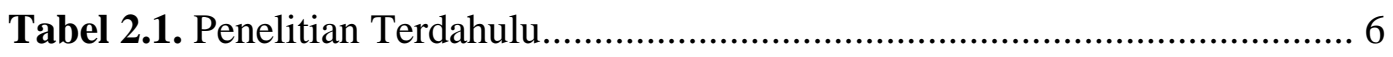

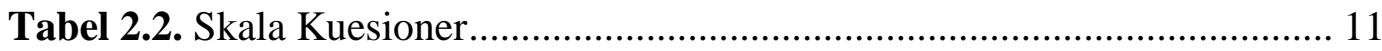

Tabel 3.1. Task dan Skenario I (Website : azstore.id)....................................... 13

Tabel 3.2. Task dan Skenario II (Website : kaos3dmalang.com)........................ 13

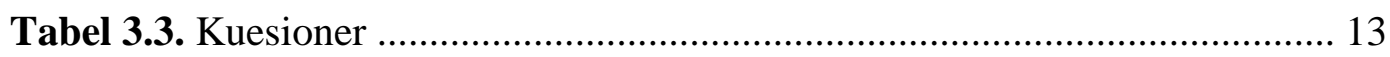

Tabel 3.4. Tabel Kategori Kelayakan_......................................................... 17

Tabel 3.5. Task Dan Skenario I _........................................................................ 18

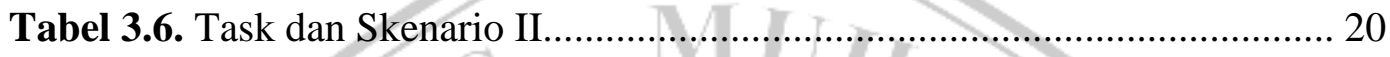

Tabel 4.1. Tabel Pengukuran Usability Website Azstore.id ............................. 25

Tabel 4.2. Tabel Pengukuran Usability Website kaos3dmalang.com ................. 25

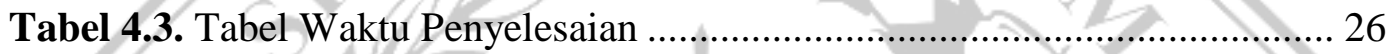

Tabel 4.4. Jumlah Fikasasi ................................................................ 27

Tabel 4.5. Pedoman Untuk Memberikan Interpretasi Koefisien Korelasi .......... 31

Tabel 4.6. Uji Korelasi Website Azstore.id.................................................. 31

Tabel 4.7. Uji Korelasi Website kaos3dmalang.com ........................................ 31 


\section{DAFTAR PUSTAKA}

[1] H. Aryadita, D. A. Widyastuti, and N. H. Wardani, "Analisis Kualitas Layanan Website E-Commerce Terhadap Kepuasan Pengguna Menggunakan Metode Webqual 4.0," Anal. Kualitas Layanan Website ECommerce Terhadap Kepuasan Pengguna Menggunakan Metod. Webqual 4.0, vol. 10, no. 1, pp. 29-35, 2017, doi: 10.15408/sijsi.v10i1.7747.

[2] I. Salamah, H. Lindawati, P. N. Sriwijaya, and I. Quality, “ANALISIS KUALITAS WEBSITE E-COMMERCE UMKM KAIN TENUN SONGKET," vol. 7, no. 2, pp. 115-122, 2017.

[3] B. Kaysı and Y. Topaloğlu, "Usability in E-Commerce Websites: Results of Eye Tracking Evaluations," World Acad. Sci. Eng. Technol. Int. J. Comput. Syst. Eng., vol. 12, no. 10, pp. 951-957, 2018, doi: doi.org/10.5281/zenodo. 1475048 .

[4] D. R. Rahadi, "Pengukuran Usability Sistem Menggunakan Use Questionnaire Pada Aplikasi Android Interface pengguna Android didasarkan pada manipulasi langsung menggunakan masukan sentuh yang serupa dengan tindakan di dunia nyata, seperti menggesek ( swiping), mengetuk," vol. 6, no. 1, pp. 661-671, 2014.

[5] J. Wang, P. Antonenko, M. Celepkolu, Y. Jimenez, E. Fieldman, and A. Fieldman, "Exploring Relationships Between Eye Tracking and Traditional Usability Testing Data," Int. J. Hum. Comput. Interact., vol. 35, no. 6, pp. 483-494, 2019, doi: 10.1080/10447318.2018.1464776.

[6] Y. A. Purnomo, T. Suratno, P. Studi, S. Informasi, and U. Jambi, "KORELASI ANTARA FIXATION EYE TRACKING METRIC DENGAN," vol. 2, no. 2, pp. 25-34, 2019.

[7] R. Firmansyah, "Usability Testing Dengan Use Questionnaire Pada Aplikasi Sipolin Provinsi Jawa Barat," Swabumi, vol. 6, no. 1, pp. 1-7, 2018, doi: 10.31294/swabumi.v6i1.3310.

[8] R. T. Yunandar and Priyono, "Pengujian Usability System Framework React Native dengan Expo untuk Pengembang Aplikasi Android Menggunakan Use Questionnaire,” J. Penelit. Tek. Inform., vol. 3, no. 1, pp. 252-259, 2018.

[9] L. C. Maudlin, K. S. McNeal, H. Dinon-Aldridge, C. Davis, R. Boyles, and 
R. M. Atkins, "Website usability differences between males and females: An eye-tracking evaluation of a climate decision support system," Weather. Clim. Soc., vol. 12, no. 1, pp. 183-192, 2020, doi: 10.1175/WCAS-D-180127.1.

[10] T. Yogasara, Y. Theopilus, K. Damayanti, and S. Susilo, "Pengaruh dan Rekomendasi Ukuran, Lokasi, dan Unsur Dinamis Terhadap Efektivitas Iklan Website Berdasarkan Uji Anova Dengan Eye Tracking," Lemb. Penelit. dan Pengabdi. Kpd. Masy., 2018.

[11] K. Aelani and Falahah, "Pengukuran Usability Sistem Menggunakan Use Questionnaire," Semin. Nas. Apl. Teknol. Inf. 2012 (SNATI 2012), vol. 2012, no. Snati, pp. 15-16, 2012.

[12] A. Josi, "Penerapan Metode Prototyping Dalam Membangun Website Desa (Studi Kasus Desa Sugihan Kecamatan Rambang),"Jti, vol. 9, no. 1, pp. 50$57,2017$.

[13] L. D. Farida, "Pengukuran User Experience Dengan Pendekatan Usability [Kasus: Website Pariwisata Di Asia Tenggara],"Semin. Nas. Teknol. Inf. dan Multimed., pp. 6-7, 2016.

[14] N. Asnawi, "Pengukuran Usability Aplikasi Google Classroom Sebagai Elearning Menggunakan USE Questionnaire (Studi Kasus: Prodi Sistem Informasi UNIPMA)," Res. Comput. Inf. Syst. Technol. Manag., vol. 1, no. 01, p. 17, 2018, doi: 10.25273/research.v1i1.2451.

[15] Patryk Boczon, "State of the Art: Eye Tracking Technology and Applications," State Art Eye Track. Technol. Appl., vol. 53, no. 9, pp. 16891699, 2014.

[16] P. Jennifer Romano Bergstrom dan A. J. Schall, Eye Tracking in User Experience Design. 2014.

[17] D. S. Rini Agustina1, "Indexing Pada Ebook Perancangan dan Pembuatan Aplikasi Website E-,” 2018.

[18] S. Alfidella, D. S. Kusumo, and D. D. J. Suwawi, "Pengukuran Usability ICaring Berbasis ISO 9241-11 Dengan Menggunakan Partial Least Square (PLS)," eProceedings Eng., vol. 2, no. 1, pp. 1747-1735, 2015.

[19] E. S. Rahman and D. Vitalocca, “ANALISIS USABILITAS MENGGUNAKAN USE QUESTIONNAIRE PADA SISTEM 
INFORMASI SMK NEGERI 3 MAKASSAR,” J. Mekom, pp. 1-17, 2018.

[20] D. S. Pratomo and E. Z. Astuti, "Analisis Regresi dan Korelasi Antara Pengunjung dan Pembeli Teradap Nominal Pembelian di Indomaret Kedungmundu Semarang Dengan Metode Kuadrat Terkecil,” Ilmu Komput., no. 1, 2015.

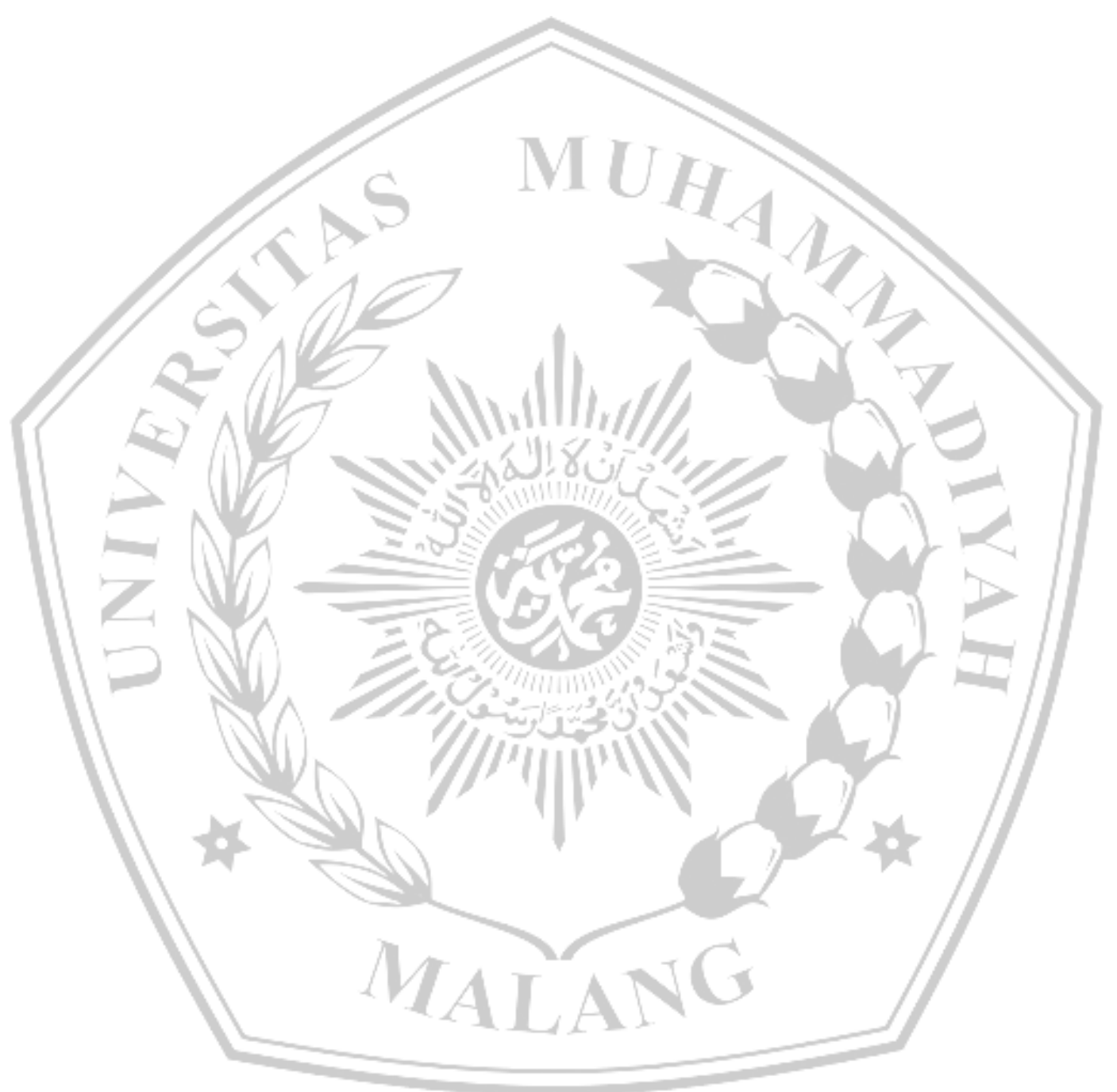




\section{UNIVERSITAS MUHAMMADIYAH MALANG FAKULTAS TEKNIK PROGRAM STUDI TEKNIK INFORMATIKA}

Jl. Raya Tlogomas 246 Malang 65144 Telp. 0341 - 464318 Ext. 247, Fax. 0341 - 460782

\section{FORM CEK PLAGIARISME LAPORAN TUGAS AKHIR}

Nama Mahasiswa : Gita Ismadianti

NIM

: 201610370311142

Judul TA

: Analisis Perbandingan Usability Website E-Commerce Konveksi Menggunakan Metode Eye Tracking

Hasil Cek Plagiarisme dengan Turnitin

\begin{tabular}{|l|l|c|c|}
\hline No. & \multicolumn{1}{|c|}{ Komponen Pengecekan } & $\begin{array}{c}\text { Nilai Maksimal } \\
\text { Plagiarisme (\%) }\end{array}$ & $\begin{array}{c}\text { Hasil Cek Plagiarisme } \\
(\%) *\end{array}$ \\
\hline 1. & Bab 1 - Pendahuluan & $10 \%$ & $6 \%$ \\
\hline 2. & Bab 2 - Daftar Pustaka & $25 \%$ & $10^{6} \zeta$ \\
\hline 3. & Bab 3 - Analisis dan Perancangan & $25 \%$ & $21 \%$ \\
\hline 4. & Bab 4 - Implementasi dan Pengujian & $15 \%$ & $10 \zeta$ \\
\hline 5. & Bab 5 - Kesimpulan dan Saran & $5 \%$ & 46 \\
\hline 6. & Makalah Tugas Akhir & $20 \%$ & $8 \%$ \\
\hline
\end{tabular}

Mengetahui,

Dosen Pembimbing

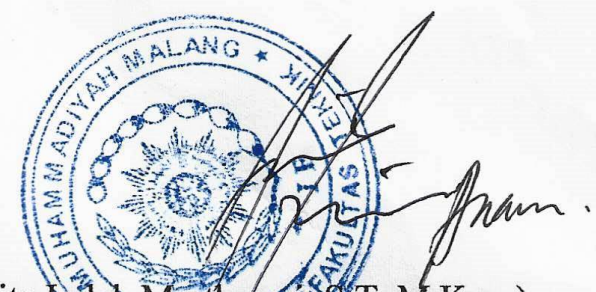

(Gita Indab.Marthosary s.T, M.Kom)

*) Hasil cek plagtarism bisa diisikkan oleh salah satu pembimbing 